ИЗВЕСТИЯ АКАДЕМИИ НАУК ЭСТОНСКОИ ССР. ТОМ 27 ХИМИЯ. 1978, 수 1

Ю. КАУП, Марина ГРИНЧАК, О. ЭЙЗЕН

удК $541.13: 547.538 .141$

\title{
ПРЕВРАЩЕНИЕ СТИРОЛА В ВОДОРОДНОЙ ПЛАЗМЕ ВЧ-ТЛЕЮЩЕГО РАЗРЯДА
}

J. KAUP, Marina GRINTSAK, O. EISEN. STUREENI REAKTSIOONID VESINIKU , HUUMLAHENDUSPLASMAS

J. KAUP, Marina GRINCHAK, O. EISEN. REACTIONS OF STYREN IN HYDROGEN PLASMA OF A HF GLOW DISCHARGE

Нами найдено ['], что превращение фенилацетилена в водородной плазме протекает в нескольких направлениях и включает реакции присоединения водорода, распада, отщепления и полимеризации. На основе полученных данных невозможно сказать, имеет ли место прямое присоединение водорода к тройной связи, или продукты присоединения водорода образуются в результате вторичных процессов.

В целях уточнения механизма взаимодействия водорода с ненасыщенными соединениями в ВЧ-тлеющем разряде нами проведено исследование превращения стирола в водородной плазме. Для этого использовали аппаратуру и условия, аналогичные приведенным в [2,3]. Действию разряда подвергали смесь стирола с водородом (молярное соотношение $1: 5)$. Мощность разряда варьировали от 110 до 310 мA по анодному току. Рабочая частота $-13,56$ МГц.

Установлено (таблица), что в результате взаимодействия стирола с водородом в тлеющем разряде образуются в основном насыщенные

Зависимость продуктов реакции от степени превращения стирола, \%

\begin{tabular}{l|r|r|r|r|r|r}
\hline \multirow{2}{*}{ Продукты } & \multicolumn{7}{c}{ Степень превращения, \% } \\
\cline { 2 - 6 } & 19,7 & 37,1 & 66,3 & 81,3 & 95,5 & 98,6 \\
\hline & 0,15 & 0,47 & 1,52 & 2,37 & 5,27 & 5,47 \\
Бензол & 0,07 & 0,42 & 1,19 & 1,85 & 4,62 & 5,83 \\
Толуол & 0,82 & 2,17 & 4,50 & 4,89 & 6,21 & 3,33 \\
Этилбензол & 0,03 & 0,07 & 0,13 & 0,17 & 0,36 & 0,31 \\
Ксилолы & 80,30 & 62,94 & 33,74 & 18,74 & 4,54 & 1,43 \\
Стирол & 0,41 & 0,77 & 2,22 & 2,32 & 1,18 & 0,46 \\
Фенилацетилен & & & & & & \\
Неидентифицированные & 1,09 & 1,67 & 5,87 & 5,57 & 8,21 & 8,03 \\
жидкие продукты & 5,75 & 9,41 & 14,48 & 11,06 & 15,01 & 16,54 \\
Метан & 0,31 & 1,39 & 1,15 & 5,16 & 4,32 & 8,15 \\
Этан & 0,50 & 0,66 & 0,36 & 2,06 & 1,40 & 2,24 \\
Этилен & 1,18 & 1,25 & 1,14 & 2,72 & 2,48 & 4,56 \\
Ацетилен & 9,39 & 18,78 & 33,70 & 43,09 & 46,40 & 43,65 \\
Полимерные соединения & & & &
\end{tabular}


углеводороды. Фенилацетилен и ацетилен образуются в небольших количествах.

Степень превращения стирола в тлеющем разряде практически линейно зависит от мощности разряда. При этом интересно отметить, что содержание этилбензола, а также фенилацетилена и полимеров проходит через максимум.

Как известно из предыдущих работ, фенилацетилен ['] в отличие от ацетилена $\left.{ }^{2}\right]$ гидрировался в водородной плазме до стирола и этилбензола в сумме лишь до $2 \%$, а общее содержание гидрированных форм составляло $\sim 10 \%$. В случае превращения стирола при такой же мощности разряда, как и в $\left[{ }^{1,2}\right]$, суммарное содержание гидрированных форм углеводородов доходило до $40 \%$.

На основе полученных данных можно предположить, что после отщепления $\mathrm{CH}_{2}$ или $\mathrm{C}_{2} \mathrm{H}_{3}$ от стирола ароматические остатки полимеризуются

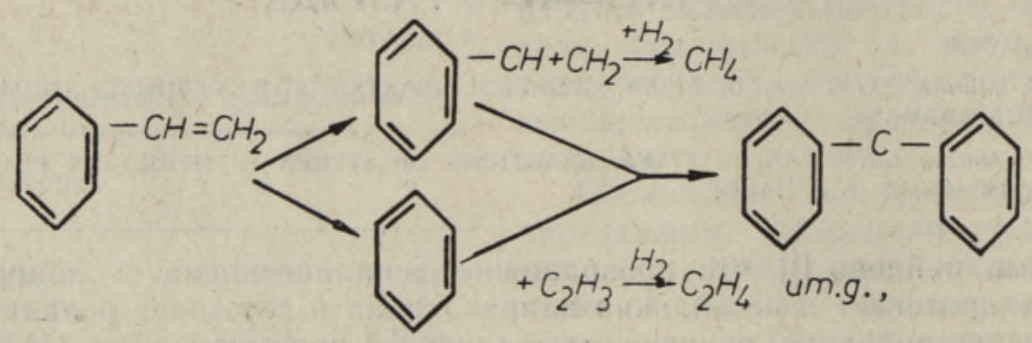

и т. д.,

так как суммарное содержание углеводородов $\mathrm{C}_{1}$ и $\mathrm{C}_{2}$ в несколько раз превышает суммарное содержание бензола и толуола.

Метан, по всей вероятности, образуется в результате гидрирования $\mathrm{CH}_{2}$, а также вследствие вторичных процессов разложения углеводородов $\mathrm{C}_{2}$. Такого же мнения придерживаются и другие авторы [4,5].

Сравнительно высокое содержание этилбензола (до 6,25\%) позволяет предполагать, что он образуется в результате присоединения водорода к двойной связи стирола.

\section{Л И ТЕ РА Т У Р А}

1. К а уп Ю., Грин ч а к Марина, Эй зен О., Изв. АН ЭССР. Хим. Геол., 26, № 4 (1977).

2. К а уп Ю. Ю., Э й з ен О. Г., Химия высоких энергий, ХI, 100 (1977).

3. К а уп Ю., Эй з е н О., Изв. АН ЭССР. Хим. Геол., 26, 18 (1977).

4. Б е беш ко Г. И., Е р е м н н Е. Н., Ж. физ. химии, 48, 609 (1974).

5. Бе бе ш к о Г. И., Е р е м и н Е. Н., Ж. физ. химин, 48, 611 (1974).

Институт химии

Академии-маук Эстонской ССР
Поступила в редакцию 30/VI 1977 